International Journal of

Supply Chain

Management

(IJSCM)

\title{
QUALITY MANAGEMENT PRACTICES AND COMPETITIVENESS OF MANUFACTURING FIRMS IN NAIROBI
}

Jacqueline Wangui Muiruri and Dr. Magutu Obara Peterson

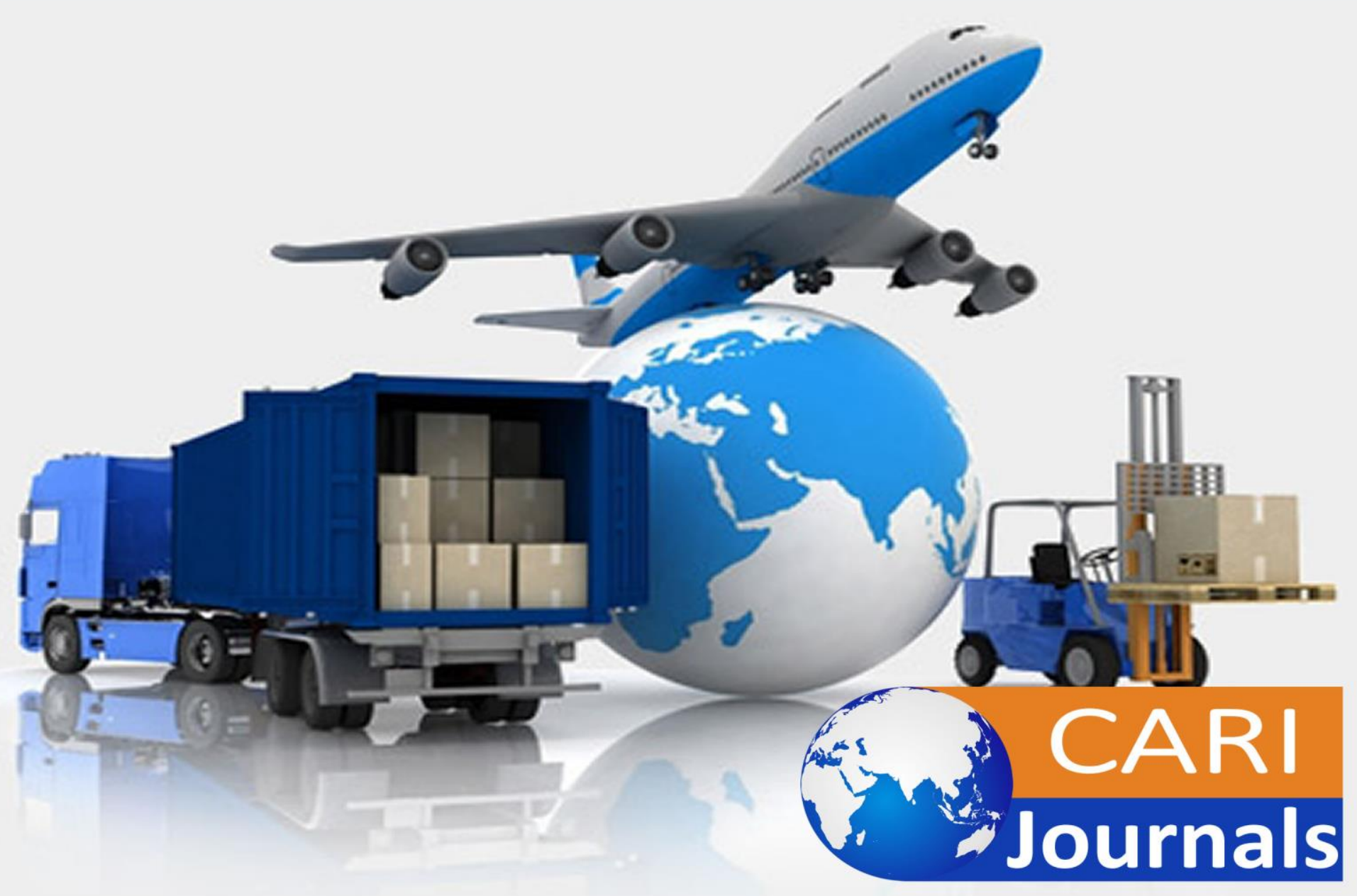




\title{
QUALITY MANAGEMENT PRACTICES AND COMPETITIVENESS OF MANUFACTURING FIRMS IN NAIROBI
}

\author{
1 *Jacqueline Wangui Muiruri \\ Post Graduate Student: School of Business, \\ University of Nairobi \\ *Corresponding Author's E-mail: jacquie.muiruri@gmail.com \\ $2^{*}$ Dr. Magutu Obara Peterson \\ Lecturer, Department of Management Science \\ University of Nairobi
}

\begin{abstract}
Purpose: The main objective of this study was to establish the influence of quality management practices on competitiveness of manufacturing firms in Nairobi.

Methodology: The research adopted a descriptive survey research design in trying to focus on manufacturing firms operating in Nairobi. This study used the list of manufacturing firms in Nairobi as provided in the KAM directory that showed a total of 499 manufacturing firms operating in Nairobi. The research study used stratified random sampling. The sample size of the research study was 50 manufacturing firms. The data was collected by use of structured questionnaires. It was done from operations managers, quality assurance managers and supply chain managers or their equivalents since they were deemed to be well versed and had good understanding of strategic quality management practices and operational activities of manufacturing firms. The information from the analysis was presented by use of pie charts, graphs, bar charts and tables to search for any correlation between strategic quality management practices and firms' competitiveness.

Results and conclusion: The results revealed that bench marking and competitiveness were positively and significantly correlated $(\mathrm{r}=0.578, \mathrm{p}=0.000)$. The results further showed that continuous improvement and competitiveness were positively and significantly related $(r=0.620$, $\mathrm{p}=0.000$ ). It was additionally verified that supplier partnering and competitiveness were positively and significantly related $(\mathrm{r}=0.510, \mathrm{p}=0.000)$. Equally, the results showed that six sigma and competitiveness were positively and significantly related $(r=0.529, \mathrm{p}=0.000)$. Finally, the results revealed that quality management practices and competitiveness were positively and significantly related $(\mathrm{r}=0.642, \mathrm{p}=0.000)$. The results indicated that the overall model was statistically significant. Further, the results imply that the independent variables are good predictors of firm competitiveness. This was reinforced by an F statistic of 21.769 and the reported p value (0.000) which was less than the conventional probability of 0.05 significance level.
\end{abstract}


International Journal of Supply Chain and Logistics

ISSN 2520-3983 (online)

Vol.4, Issue No.1, pp 27 - 45, 2020

www.carijournals.org

Policy recommendation: The author recommended that manufacturing firms should institute and involve the support of strategic leadership to monitor the adoption and implementation of quality management practices as a way of improving their competitiveness in their respective industries. Further, firms should come up with as many benchmarking approaches and to also hold several of them so as to increase on adoption of effective mechanism that makes firms more competitive.

Keywords: Benchmarking practices, Supplier Partnering Practices, Continuous Improvement Practices, Quality Management Practices Six Sigma Practices.

\subsection{INTRODUCTION}

The rising demand for better quality products and services by customers has led firms to focus on quality practices in order to compete successfully in a high intense competitive environment. According to Anderson (2004) strategic management activity within firms ensures continuous improvement of the quality of services, products and processes by having customer's perspective in mind to meet and exceed customers' needs.

Strategic quality management (SQM) practices are managerial techniques set through managerial tendencies of planning, improvement and control. Deming (2006) defined quality as a predictable degree of uniformity and dependability which can be achieved at low cost. SQM varies from one firm to another but it has certain essential principles which can be adopted to ensure efficiency in operations, cost reduction, increased market share and high profitability (Kanji \& Wallace, 2000).

Competitiveness means the ability of firms and organizations to effectively meet the needs and wants of customers. Porter (2004) defines competitiveness as the abundance obtained through value addition when goods and services are offered to the market above their production cost. Firm's competitiveness is the ability of a firm to withstand different external forces and challenges existing in the external business environment. It refers to the different strategies employed by different firms to face economic turbulence within the external environment and they include adopting different technologies that are unique to the industry, using the firm's brand as a competitive tool as well as preparing staff for any technicalities that may arise within their line of work (Cobb, 2003).

The Kenya Association of Manufacturers (2017) states that there are 700 manufacturing firms in Kenya and 499 manufacturing firms in Nairobi County. The manufacturing industry in Kenya is dominated by different types of firms dealing in various production operations and activities which are categorized into; textile, chemicals, electronics, pharmaceuticals, food and beverages, beauty products, paper, timber, plastics and leather products. Most output from these manufacturing firms constitute of basic supplies like construction materials, food and beverages with only 5\% constituting of skill intensive manufactured items such as medicinal drugs and pharmaceuticals. There is need for these firms to be competitive for them to survive in turbulent environment.

\subsection{Problem Statement}

Strategic quality management practices are the effective methods for which firms can achieve improved organizational performance and gain competitive edge in a cut-throat competitive industry, for they ensure monitoring of the firm's operations in order to have high quality products 
International Journal of Supply Chain and Logistics

ISSN 2520-3983 (online)

Vol.4, Issue No.1, pp 27 - 45, 2020

www.carijournals.org

hence meeting and exceeding customers' satisfaction. These practices have led to customers' loyalty, efficiency in operation and increase in productivity level.

In many emerging economies, manufacturing firms have been the engine of growth in the countries. According to KAM (2012) Kenya enjoys a continuous growth of $4 \%$ over the last decade. In the last 15 years the manufacturing industry was one of the largest sector of the economy after agriculture (Republic of Kenya, 2008) but it has gradually reduced its prominence to the fourth place after transport and communication, agriculture, retail and wholesale trade (World Bank, 2012). The sector has seen a reduction of GDP contribution from 13.6 percent to 9.2 percent (Republic of Kenya, 2013). There is emphasis for manufacturing firms to strategize for efficient and sustainable practices as a way of making the organizational products and services to be locally and globally competitive and successful (RoK, 2007).

According to United Nations Environmental Program (2015) manufacturing firms in Kenya are burdened by resources scarcity, low level of technology utilization, unreliable supply of electricity, declining trend of product innovation and high cost of energy. Nonetheless, there has been an average growth of 4.1 percent from 2006 to 2013 but this was minimal compared to the average GDP of 4.6 percent. Achuora et al., (2015) states that most manufacturing firms in Nairobi County operate at a technical efficiency of 59\% compared to other countries such as Malaysia that average about $74 \%$. This leads to the question of the ability of the manufacturing firms in Nairobi to be competitive in the market. Thus, there is need for large scale manufacturing firms' in Nairobi to conform to the best strategic quality management practices in order to have consistence performance in their operations and to enhance on providing high quality products and services in order to remain competitive in the market.

Globally, Terziovski \& Power (2007) found out that in two years after firms adopted quality management practices like ISO certification, the rate of return of the selected firms demonstrated a 35 percent rise than those of non-ISO certified. Fotopoulos et al. (2010) determined that there is a substantial connection between ISO certification and firm's performance. Quanzi \&Padibjo (1998) noted that there is no significant association between quality management practices and firm's performance. However, these studies were done from different countries and a different type of industry of operation

Locally, various studies have been conducted on the relationship between quality practices with an aspect of performance. Wachira (2013) established that firms' performance in a competitive environment is largely affected by the implementation of QM practices at 75.5 percent. Mutua (2014) found out that manufacturing firms that adopted quality management practices were sustainability and performed better. However, no studies have been carried out to show the association between strategic quality management practices and firms' competitiveness in manufacturing firms in Nairobi.

It is clear that previous literatures on the study topic have not provided comprehensive and adequate proof about SQM practices implemented in the manufacturing sector and the relationship between SQM practices and competitiveness of manufacturing firms in Nairobi County. This research study seeks to answer the question; what are some of the SQM practices implemented in 
International Journal of Supply Chain and Logistics

ISSN 2520-3983 (online)

Vol.4, Issue No.1, pp 27 - 45, 2020

$\underline{\text { www.carijournals.org }}$

manufacturing firms' in Nairobi? What is the relationship between SQM practices and competitiveness of manufacturing firms in Nairobi?

\subsection{Objectives of the Study}

i. To determine the extent to which strategic quality management practices were adopted in manufacturing firms in Nairobi County.

ii. To establish the relationship that may exist between strategic quality management practices and competitiveness of manufacturing firms in Nairobi County.

\subsection{LITERATURE REVIEW}

\subsection{Quality Improvement Theory}

This theory proposes that quality management component requires the involvement and support of the strategic administration to operate well (Deming, 1986). According to Hill, 1995, he recognizes that strategic functions are responsible for the practices that produce $80 \%$ of the issues in the organization. The strategic management personnel play a bigger role on the quality management practices because they ultimately decide on the resources to deploy, procedures to link the operations and the control measures of the SQM practices. Deming's quality improvement theory states that low quality control practices through strategic administrative involvement will enhance improvement of operations within the firm and contribute towards sustainability.

According to Hubert (2000), in his hypothetical approach on Deming's quality improvement theory, he established a hierarchical framework that stimulates participation and inventing ways to implement the process of administration that leads to radical changes in the processes, procedures and administrative functions that are focused towards the customer while at the same time contributing towards the sustainability of the firm. Deming (2004) put into consideration the Plan Do Check Act (PDCA) cycle as an all-inclusive quality change practice. The hypothetical essence of the quality improvement theory puts emphasis on reducing the number of defects occurring in the manufacturing processes by making strategic frameworks and procedures that enhance participation and learning of the firms' processes, which prompt implementations of SQM practices (Anderson et al., 1994). The theory is vital in our research study for it provides the importance of the strategic management in the planning and execution of the quality management practices in the firms.

\subsection{Strategic Quality Management Practices}

\subsubsection{Benchmarking practices}

Benchmarking practices are a continuous process for measuring goods, services and practices in comparison to the leading firms in the industry. The best performing organization are used as yardsticks against the organization that is evaluating itself (Carigo\& Maria, 2006). In manufacturing firms, there are two types of benchmarking that are used to assess quality; competitive benchmarking which involves a firm evaluating itself with their direct competitors (Wright \& Richard, 2007) and non-competitive benchmarking that involves measuring the firm against the trend setters in terms of quality regardless of the industry of the firms thus the firm can 
International Journal of Supply Chain and Logistics

ISSN 2520-3983 (online)

Vol.4, Issue No.1, pp 27 - 45, 2020

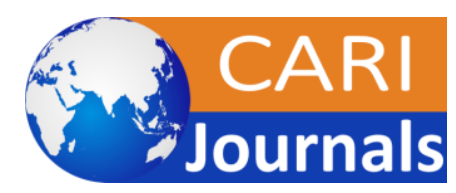

www.carijournals.org

identify and adopt the best practices implemented in the company (Wilkinson, Adrian \& Hugh, 2006).

\subsubsection{Supplier Partnering Practices}

Manufacturing firms partner directly with their suppliers of components and parts in order to enhance quality at their suppliers' location (Wilkinson, Adrain\& Hugh, 2006). This involves creating close working relationships that entails direct participation between manufacturing firm and their suppliers in terms of technical assistance, materials delivery, assembly of components and other transactional details (Van de and Vliet, 2009).

\subsubsection{Continuous Improvement Practices}

Continuous Improvement (CI) practice is a technique of SQM that enhances improvement of processes and firm's operations that leads to increased competitiveness by improving on the company's internal resources (Porter \& Anne, 2007).Improvement can involve increasing the level of customer satisfaction or producing zero defect products. The CI practice uses identical principles despite the difference in the goals of the processes (Murphy \& Elana, 2006). These principles includes improvement of the existing processes, participation and involvement of the firm's corporate levels which involves data collection on the firms' operations and quantifying the data that forms the basis of improvement that will be measured for continuous improvement (Morgan, 2006).

\subsubsection{Quality Management practices}

Quality Management practices have become essential in the business world. Most manufacturing firms are conforming to international standards in order for the product to compete locally, regionally and globally.The International Organization for Standardization (ISO 9000) is a series of international standards on quality assurance and quality management that state how strategic activities are to be carried out in a firm to guarantee that quality is reflected in the final goods and products. Manufacturing firms must conform and adhere to the set standards for firms by ensuring that quality is achieved (Martin, 2007).

\subsubsection{Six sigma}

Six sigma is a strategic quality management practice implemented by manufacturing firms for reduction of defects and General Electric's Jack Welch initiated it. It is a practice that improves the efficiency of the firm's operations and increases the quality of the finished products by eliminating wastes and mitigating frequency of errors that occur during production of products in manufacturing firms. Implementation of six sigma ensures that firms do not experience stock outs and obsolete stocks (Davenport et al., 2006). 
International Journal of Supply Chain and Logistics

ISSN 2520-3983 (online)

Vol.4, Issue No.1, pp 27 - 45, 2020

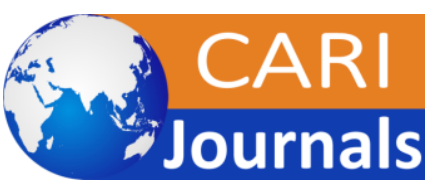

www.carijournals.org

\subsection{Conceptual Framework} SQM PRACTICES

\section{FIRM'S COMPETITIVENESS}

Bench Marking

Six Sigma

Continuous Improvement

Supplier Partnering

Quality Management
Productivity

Cost Minimization

Efficiency Improved

Performance

Consistency

\section{Figure 1: Conceptual framework}

\subsection{METHODOLOGY}

The research adopted a descriptive survey research design in trying to focus on manufacturing firms operating in Nairobi. This study used the list of manufacturing firms in Nairobi as provided in the KAM (2017) directory that showed a total of 499 manufacturing firms operating in Nairobi. The research study used stratified random sampling. The sample size of the research study was 50 manufacturing firms.

\section{Table 1: Sampling Frame}

\begin{tabular}{lccc}
\hline SECTOR & NO. OF FIRMS & \% AGE & RESPONDENT \\
\hline Energy, electrical \& electronics & 34 & 6.8 & 3 \\
Building, mining \& Construction & 20 & 4 & 2 \\
Chemical \& Allied Sector & 70 & 14 & 7 \\
Food \& Beverages & 71 & 14.2 & 7 \\
Leather \& Footwear & 7 & 1.4 & 1 \\
Metal \& Allied Sector & 66 & 13.2 & 7 \\
Motor vehicles \& Accessories & 27 & 5.4 & 3 \\
Pharmaceutical \& Medical Equipment & 21 & 4.2 & 2 \\
Paper \& Board Sector & 63 & 12.6 & 6 \\
Plastics \& Rubber & 68 & 13.6 & 7 \\
Textile \& Apparels & 35 & 7 & 4 \\
Furniture, timber \& Wood & 17 & 3.4 & 2 \\
TOTAL & $\mathbf{4 9 9}$ & $\mathbf{1 0 0}$ & $\mathbf{5 0}$ \\
\hline
\end{tabular}

The data was collected by use of structured questionnaires. It was done from operations managers, quality assurance managers and supply chain managers or their equivalents since they were deemed to be well versed and had good understanding of strategic quality management practices and operational activities of manufacturing firms. The information from the analysis was presented 
International Journal of Supply Chain and Logistics

ISSN 2520-3983 (online)

Vol.4, Issue No.1, pp 27 - 45, 2020

$\underline{\text { www.carijournals.org }}$

by use of pie charts, graphs, bar charts and tables to search for any correlation between strategic quality management practices and firms' competitiveness.

$y=\alpha+\beta_{1} X_{1}+\beta_{2} X_{2}+\beta_{3} X_{3}+\beta_{4} X_{4}+\beta_{5} X_{5}+\beta_{6} X_{6}+\varepsilon$

Where:

$\mathrm{y}=$ Firms' Competitiveness

$\alpha$ =Constant; $\mathrm{y}$ intercept, that is, the value of $\mathrm{y}$ when $\mathrm{x}$ is equal to zero

$\beta_{1} \ldots \beta_{5}=$ the slope/gradient that represents the degree of change in independent variable by oneunit variable

$\mathrm{X}_{1}=$ Benchmarking practices

$\mathrm{X}_{2}=$ Supplier partnering practices

$\mathrm{X}_{3}=$ Continuous improvement practices

$\mathrm{X}_{4}=$ Quality management practices

$\mathrm{X}_{5}=$ Six Sigma practice

$\varepsilon=$ error term

\subsection{RESULTS FINDINGS}

\subsection{Descriptive Statistics}

\subsubsection{Bench marking by manufacturing firms}

This study aimed at determining the various SQM practices adopted by manufacturing firms in Nairobi County. The first SQM practice tested was bench marking. Various statements were used to test on applicability of this practice among manufacturing firms in Nairobi. These results are shown in table 2.

In the first statement the organization conducts a continuous procedure of measuring goods, services and practices against those ones of the competitors. Most of the respondents were to a large extent agreeing with this statement at $86 \%(48 \%+38 \%)$.

The second statement was that their company does comprehensive comparison against the best performing companies both locally and globally. Majority of the respondents were also in agreement with this statement as shown by a mean of 4 and a standard deviation of 1 .

These results were in agreement with past study results for instance; Carigo and Maria (2006) argued that the best performing organization are used as yardsticks against the organization that is evaluating itself. The third question was that the manufacturing firm through comparison is able to identify the weakness of the operations and work towards improving it and majority of the respondents were in agreement with it (mean $=4$, standard deviation=1).

Finally, if the organization practiced competitive comparison with the firms dealing with the same products. Majority of the respondents were in agreement with it (mean=4, standard deviation=1). From this sub-variable the mean for all the statements was 4 and a standard deviation of 1 meaning 
that the respondents were in agreement with all the statements. This therefore meant that bench marking was one of the various SQM practices being utilized by manufacturing firms in Nairobi County.

The findings of this study were in agreement with previous studies. Hinckley and Martin (2007) postulated that for successful implementation of benchmarking practices, a manufacturing firm must comprehensively evaluate its own practices. In addition, the study concurred with the findings of Kinni and Theodore (2005) who concluded that the firm will have an idea on the current position of its own quality issues through honest and thorough self-assessment which will identify the weaknesses and strength that needs to be improved on in order to attain firms' strategic objectives.

\section{Table 2: Bench marking}

\begin{tabular}{|c|c|c|c|c|c|c|c|}
\hline & $\begin{array}{c}\text { not at } \\
\text { all }\end{array}$ & $\begin{array}{c}\text { low } \\
\text { extent }\end{array}$ & $\begin{array}{c}\text { moderate } \\
\text { extent }\end{array}$ & $\begin{array}{c}\text { large } \\
\text { extent }\end{array}$ & $\begin{array}{c}\begin{array}{c}\text { very large } \\
\text { extent }\end{array} \\
\end{array}$ & Mean & $\begin{array}{l}\text { Standard } \\
\text { Deviation }\end{array}$ \\
\hline Our organization & & & & & & & \\
\hline $\begin{array}{l}\text { conducts a } \\
\text { continuous process of } \\
\text { measuring products } \\
\text { services and practices } \\
\text { against those ones of } \\
\text { the competitors }\end{array}$ & $0.0 \%$ & $0.0 \%$ & $14.0 \%$ & $48.0 \%$ & $38.0 \%$ & 4 & 1 \\
\hline $\begin{array}{l}\text { Our company does } \\
\text { comprehensive } \\
\text { comparison against } \\
\text { the best performing } \\
\text { companies both } \\
\text { locally and globally }\end{array}$ & $0.0 \%$ & $0.0 \%$ & $16.0 \%$ & $36.0 \%$ & $48.0 \%$ & 4 & 1 \\
\hline $\begin{array}{l}\text { The manufacturing } \\
\text { firm through } \\
\text { comparison is able to } \\
\text { identify the weakness } \\
\text { of the operations and } \\
\text { work towards } \\
\text { improving it }\end{array}$ & $0.0 \%$ & $0.0 \%$ & $18.0 \%$ & $50.0 \%$ & $32.0 \%$ & 4 & 1 \\
\hline $\begin{array}{l}\text { Our organization } \\
\text { practices competitive } \\
\text { comparison with the } \\
\text { firms dealing with the } \\
\text { same products }\end{array}$ & $0.0 \%$ & $0.0 \%$ & $16.0 \%$ & $56.0 \%$ & $28.0 \%$ & 4 & 1 \\
\hline Average & & & & & & 4 & 1 \\
\hline
\end{tabular}

Source: Researcher (2017) 


\subsubsection{Continuous Improvement}

The second SQM practice tested is continuous improvement. These findings are shown in table 2 below. The first statement under this sub-variable was that the firm works towards improving every operational function in the firm. Majority of the respondents were in agreement with this statement (mean $=4$, standard deviation=1). Secondly the statement of if the company produces no defects from the manufacturing operations was asked. Most respondents agreed with a (mean=4, standard deviation=1). Thirdly, the statement of whether the company achieves high levels of customer satisfaction was tested. Majority of the respondents were in agreement with this statement (mean= 4, standard deviation=1). Respondents were also tasked if there was continuous review of quality in every stage of operations. Majority of the respondents were in agreement with the statement (mean= 4, standard deviation=1). Finally, the respondents were asked to indicate the extent to which they were agreeing with the statement that a quality management team only concentrates on the quality of the products, processes and functions. Majority of them were in agreement with this statement (mean $=4$, standard deviation $=1)$. On average, the respondents were to a large extent agreeing with many of these statements (mean $=4$, standard deviation=1) and this meant that manufacturing firms had adopted continuous improvement as an SQM practice.

Table 3: Continuous Improvement

\begin{tabular}{|c|c|c|c|c|c|c|c|}
\hline & $\begin{array}{c}\text { not at } \\
\text { all }\end{array}$ & $\begin{array}{c}\text { low } \\
\text { extent }\end{array}$ & $\begin{array}{c}\text { moderate } \\
\text { extent }\end{array}$ & $\begin{array}{c}\text { large } \\
\text { extent }\end{array}$ & $\begin{array}{c}\text { very large } \\
\text { extent }\end{array}$ & Mean & $\begin{array}{l}\text { Standard } \\
\text { Deviation }\end{array}$ \\
\hline $\begin{array}{l}\text { Our company works } \\
\text { towards improving } \\
\text { every operational } \\
\text { function in the firm }\end{array}$ & $0.0 \%$ & $16.7 \%$ & $25.0 \%$ & $31.2 \%$ & $27.1 \%$ & 4 & 1 \\
\hline $\begin{array}{l}\text { Our company } \\
\text { produces no defects } \\
\text { from the } \\
\text { manufacturing } \\
\text { operations }\end{array}$ & $0.0 \%$ & $12.5 \%$ & $18.8 \%$ & $39.6 \%$ & $29.2 \%$ & 4 & 1 \\
\hline $\begin{array}{l}\text { Our company } \\
\text { achieves high levels } \\
\text { of customers } \\
\text { satisfaction }\end{array}$ & $0.0 \%$ & $20.8 \%$ & $10.4 \%$ & $33.3 \%$ & $35.4 \%$ & 4 & 1 \\
\hline $\begin{array}{l}\text { There is a continuous } \\
\text { review of the quality } \\
\text { in every stage of the } \\
\text { operations }\end{array}$ & $2.1 \%$ & $4.2 \%$ & $25.0 \%$ & $39.6 \%$ & $29.2 \%$ & 4 & 1 \\
\hline $\begin{array}{l}\text { We have a quality } \\
\text { management team } \\
\text { that only concentrates } \\
\text { on the quality of the } \\
\text { products, processes } \\
\text { and functions }\end{array}$ & $8.3 \%$ & $0.0 \%$ & $16.7 \%$ & $35.4 \%$ & $39.6 \%$ & 4 & 1 \\
\hline Average & & & & & & 4 & 1 \\
\hline
\end{tabular}


Source: Researcher (2017)

\subsubsection{Supplier Partnering}

The researcher went on to establish whether manufacturing firms in Nairobi were utilizing supplier partnering as an SQM practice. Respondents were asked whether their firms work collaboratively with their suppliers to improve the quality of the products and processes. Majority of them were to a large extent agreeing with this statement (mean= 4, standard deviation=1). Secondly the respondents were asked if their firms practice outsourcing of some non-core activities in order to concentrate on their core products production. Majority of them were to a large extent agreeing with this statement (mean=4, standard deviation=1). In addition, the statement of whether their firms share the statistical controls being used in the company with the supplier in order to ensure high quality of products. Majority of them were to a large extent agreeing with this statement (mean $=4$, standard deviation=1). Finally, the question of whether their firms also outsource some services in order to cut down on the operational cost or production cost was asked. Majority of them were to a large extent agreeing with this statement (mean=4, standard deviation=1). On fivepoint scale, the mean of all these statements was 4 and a standard deviation of 1 meaning that majority of the respondents agreed to a large extent with these statements. The researcher thus concluded that supplier partnering was an SQM practice being used by manufacturing firms in Nairobi. These results are shown in table 3 below. This study concurred with one that states that manufacturing firms liase with their suppliers of parts and components in order to advance on quality from their suppliers' location Wilkinson, Adrain \& Hugh (2006). In addition, the study was in agreement with a previous study that argued that supplier partnering practice needs a continuous and consistent communication as well as feedback on the improvement of the operations because suppliers usually have an ideal perspective of the industry and can help the manufacturing firms achieve operational excellence thus being competitive in the industry Heller \& Robert (2004). 
International Journal of Supply Chain and Logistics

ISSN 2520-3983 (online)

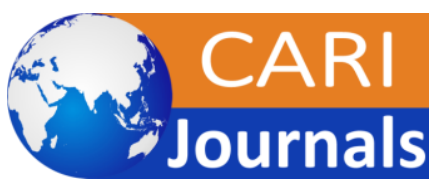

Vol.4, Issue No.1, pp 27 - 45, 2020

www.carijournals.org

Table 4: Supplier Partnering

\begin{tabular}{|c|c|c|c|c|c|c|c|}
\hline & not at all & ow extent & $\begin{array}{c}\text { moderate } \\
\text { extent }\end{array}$ & large extent & $\begin{array}{c}\text { very large } \\
\text { extent }\end{array}$ & Mean & $\begin{array}{l}\text { Standard } \\
\text { Deviation }\end{array}$ \\
\hline $\begin{array}{l}\text { The firm works } \\
\text { collaboratively with the } \\
\text { supplier of the company } \\
\text { to improve the quality of } \\
\text { the products and } \\
\text { processes }\end{array}$ & $2.1 \%$ & $6.2 \%$ & $14.6 \%$ & $39.6 \%$ & $37.5 \%$ & 4 & 1 \\
\hline $\begin{array}{l}\text { Our firm practices } \\
\text { outsourcing of some non- } \\
\text { core activities in order to } \\
\text { concentrate on their core } \\
\text { products production }\end{array}$ & $4.2 \%$ & $6.2 \%$ & $27.1 \%$ & $25.0 \%$ & $37.5 \%$ & 4 & 1 \\
\hline $\begin{array}{l}\text { The firm shares the } \\
\text { statistical controls being } \\
\text { used in the company with } \\
\text { the supplier in order to } \\
\text { ensure high quality of } \\
\text { products }\end{array}$ & $0.0 \%$ & $10.4 \%$ & $20.8 \%$ & $41.7 \%$ & $27.1 \%$ & 4 & 1 \\
\hline $\begin{array}{l}\text { Our firms also outsource } \\
\text { some services in order to } \\
\text { cut down on the } \\
\text { operational cost or } \\
\text { production cost }\end{array}$ & $2.1 \%$ & $8.3 \%$ & $25.0 \%$ & $33.3 \%$ & $31.2 \%$ & 4 & 1 \\
\hline Average & & & & & & 4 & 1 \\
\hline
\end{tabular}

Researcher (2017)

\subsubsection{Six Sigma}

The researcher engaged the respondents on the aspect of Six Sigma as an SQM practice in manufacturing firms in Nairobi. Respondents were to respond to various statements. The first statement was whether there is a reduction of waste being produced from the work-in-progress. Majority of the respondents to a large extent agreed with this statement (mean=4, standard deviation=1). Secondly the respondent was asked whether there is reduction of stock-out cost and whether they produce what is exactly being demanded in the market. Majority of the respondents to a large extent agreed with this statement (mean=4, standard deviation=1). Surprisingly, for the third, fourth and fifth questions received an agreement that was to a large extent magnitude (mean= 4, standard deviation=1). These questions were: Our firm has created a reputation and good image to the customers and stakeholder due to meeting and exceeding the customers demand; Our firm works towards production of high quality products in order to have high level of customer satisfaction and finally whether there is always a reduction level of wastes being produced in the firm due to the implementation of quality mechanisms and; On average, majority of the respondents were in agreement with many of these statements (mean=4, standard deviation=1) meaning that manufacturing firms in Nairobi were adopting six sigma as an SQM practice and that it was boosting the overall firm competitiveness. These results are shown in table 4 below. These 
findings were in agreement with those of Davenport et al., (2006) who stipulated that Implementation of six sigma ensures that firms do not experience stock outs and obsolete stocks.

\section{Table 5: Six Sigma}

\begin{tabular}{|c|c|c|c|c|c|c|c|}
\hline & not at all & low extent & $\begin{array}{c}\text { moderate } \\
\text { extent }\end{array}$ & large extent & $\begin{array}{c}\text { very large } \\
\text { extent }\end{array}$ & Mean & $\begin{array}{l}\text { Standard } \\
\text { Deviation }\end{array}$ \\
\hline $\begin{array}{l}\text { Is there a reduction of } \\
\text { wastes being produced } \\
\text { from the work-in-progress }\end{array}$ & $8.3 \%$ & $0.0 \%$ & $18.8 \%$ & $31.2 \%$ & $41.7 \%$ & 4 & 1 \\
\hline $\begin{array}{l}\text { Is there reduction of stock- } \\
\text { out cost, we produce what } \\
\text { is exactly being demanded } \\
\text { in the market }\end{array}$ & $12.5 \%$ & $10.4 \%$ & $18.8 \%$ & $29.2 \%$ & $29.2 \%$ & 4 & 1 \\
\hline $\begin{array}{l}\text { Our firm has created a } \\
\text { reputation and good image } \\
\text { to the customers and } \\
\text { stakeholder due to meeting } \\
\text { and exceeding the } \\
\text { customers demand }\end{array}$ & $8.3 \%$ & $6.2 \%$ & $12.5 \%$ & $39.6 \%$ & $33.3 \%$ & 4 & 1 \\
\hline $\begin{array}{l}\text { Our firm works towards } \\
\text { production of high-quality } \\
\text { products in order to have } \\
\text { high level of customer } \\
\text { satisfaction }\end{array}$ & $6.2 \%$ & $8.3 \%$ & $25.0 \%$ & $37.5 \%$ & $22.9 \%$ & 4 & 1 \\
\hline $\begin{array}{l}\text { There is always a } \\
\text { reduction level of wastes } \\
\text { being produced in the firm } \\
\text { due to the implementation } \\
\text { of quality mechanisms }\end{array}$ & $12.5 \%$ & $6.2 \%$ & $18.8 \%$ & $35.4 \%$ & $27.1 \%$ & 4 & 1 \\
\hline Average & & & & & & 4 & 1 \\
\hline
\end{tabular}

Source: Researcher (2017)

\subsubsection{Quality Management}

Quality Management Practices as SQM practices was tested through various statements: The firm has enrolled in quality awards frameworks and competition before; We have received awards in terms of the quality of the products that meet customer demands and satisfactions; Our concentration on quality of the products, processes and function have made the firm be recognized locally, regionally and internationally through ISO Certification; Our focus is on customer satisfaction through production of quality products and services in the market; Production of the quality products has led to high demand of our product locally, regionally and globally. Surprisingly, majority of these respondents were agreeing with many of these statements as shown by a similar mean of 4 and standard deviation of 1 . The researcher then conducted a mean of all these statements and obtained a mean of 4 and standard deviation of 1 meaning that in all these statements, respondents were to a large extent agreeing with these statements. Therefore, Quality Management Practice as an SQM practice has been adopted by manufacturing firms in Nairobi. These findings are presented in table 5 below. This study was in agreement with that of Martin (2007) who states that manufacturing firms must conform and adhere to the set standards for firms by ensuring that quality is achieved. 
International Journal of Supply Chain and Logistics

ISSN 2520-3983 (online)

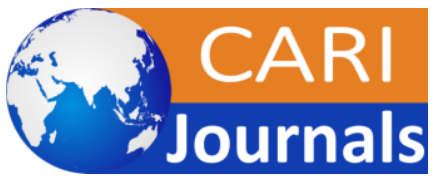

Vol.4, Issue No.1, pp 27 - 45, 2020

www.carijournals.org

Table 6: Quality Management

\begin{tabular}{|c|c|c|c|c|c|c|c|}
\hline & not at all & $\begin{array}{c}\text { low } \\
\text { extent }\end{array}$ & $\begin{array}{c}\text { moderate } \\
\text { extent }\end{array}$ & $\begin{array}{c}\text { large } \\
\text { extent }\end{array}$ & $\begin{array}{c}\text { very large } \\
\text { extent }\end{array}$ & Mean & $\begin{array}{l}\text { Standard } \\
\text { Deviation }\end{array}$ \\
\hline $\begin{array}{l}\text { The firm has enrolled in } \\
\text { the quality awards } \\
\text { frameworks and } \\
\text { competition before }\end{array}$ & $8.3 \%$ & $12.5 \%$ & $16.7 \%$ & $35.4 \%$ & $27.1 \%$ & 4 & 1 \\
\hline $\begin{array}{l}\text { We have received } \\
\text { awards in terms of the } \\
\text { quality of the products } \\
\text { that meet customer } \\
\text { demands and } \\
\text { satisfactions }\end{array}$ & $8.3 \%$ & $10.4 \%$ & $16.7 \%$ & $37.5 \%$ & $27.1 \%$ & 4 & 1 \\
\hline $\begin{array}{l}\text { Our concentration on } \\
\text { quality of the products, } \\
\text { processes and function } \\
\text { have made the firm be } \\
\text { recognized locally, } \\
\text { regionally and } \\
\text { internationally through } \\
\text { ISO Certification }\end{array}$ & $8.3 \%$ & $10.4 \%$ & $18.8 \%$ & $31.2 \%$ & $31.2 \%$ & 4 & 1 \\
\hline $\begin{array}{l}\text { Our focus is on } \\
\text { customer satisfaction } \\
\text { through production of } \\
\text { quality products and } \\
\text { services in the market }\end{array}$ & $10.4 \%$ & $14.6 \%$ & $12.5 \%$ & $31.2 \%$ & $31.2 \%$ & 4 & 1 \\
\hline $\begin{array}{l}\text { Production of the } \\
\text { quality products has led } \\
\text { to high demand of our } \\
\text { product locally, } \\
\text { regionally and globally }\end{array}$ & $10.4 \%$ & $12.5 \%$ & $12.5 \%$ & $33.3 \%$ & $31.2 \%$ & 4 & 1 \\
\hline Average & & & & & & 4 & 1 \\
\hline
\end{tabular}

Source: Researcher (2017) 
International Journal of Supply Chain and Logistics

ISSN 2520-3983 (online)

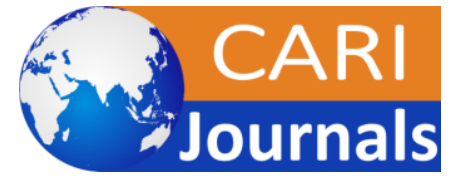

Vol.4, Issue No.1, pp 27 - 45, 2020

www.carijournals.org

\subsection{Correlation between Procurement Planning and Supply Chain Performance}

Correlation analysis was conducted in order to ascertain the relationship and strength of association between procurement planning and supply chain performance. The findings are presented in table 7 below.

Table 7: Correlation between Procurement Planning and Supply Chain Performance

\begin{tabular}{|c|c|c|c|c|c|c|c|}
\hline & & $\begin{array}{l}\text { Competitivene } \\
\text { s }\end{array}$ & $\begin{array}{l}\text { Benchmarki } \\
\text { ng }\end{array}$ & $\begin{array}{l}\text { Continuous } \\
\text { improveme } \\
\text { nt }\end{array}$ & $\begin{array}{l}\text { Supplier } \\
\text { partnering }\end{array}$ & $\begin{array}{l}\text { Six } \\
\text { sigma }\end{array}$ & $\begin{array}{l}\text { Quality } \\
\text { management }\end{array}$ \\
\hline \multirow{3}{*}{$\begin{array}{l}\text { Competitive } \\
\text { ness }\end{array}$} & $\begin{array}{l}\text { Pearson } \\
\text { Correlat } \\
\text { ion }\end{array}$ & 1 & $.578^{* *}$ & $.620^{* *}$ & $.510^{* *}$ & $.529^{*}$ & $.642^{* *}$ \\
\hline & $\begin{array}{l}\text { Sig. (2- } \\
\text { tailed) }\end{array}$ & & .000 & .000 & .000 & .000 & .000 \\
\hline & $\mathrm{N}$ & 48 & 48 & 48 & 48 & 48 & 48 \\
\hline \multirow{3}{*}{$\begin{array}{l}\text { Benchmarkin } \\
\mathrm{g}\end{array}$} & $\begin{array}{l}\text { Pearson } \\
\text { Correlat } \\
\text { ion }\end{array}$ & $.578^{* *}$ & 1 & .209 & .205 & $.551^{*}$ & $.287^{*}$ \\
\hline & $\begin{array}{l}\text { Sig. (2- } \\
\text { tailed) }\end{array}$ & .000 & & .034 & .042 & .000 & .048 \\
\hline & $\mathrm{N}$ & 48 & 48 & 48 & 48 & 48 & 48 \\
\hline \multirow{3}{*}{$\begin{array}{l}\text { Continuous } \\
\text { improvement }\end{array}$} & $\begin{array}{l}\text { Pearson } \\
\text { Correlat } \\
\text { ion }\end{array}$ & $.620^{* * *}$ & .209 & 1 & $.289^{*}$ & $.421^{*}$ & $.557^{* *}$ \\
\hline & $\begin{array}{l}\text { Sig. (2- } \\
\text { tailed) }\end{array}$ & .000 & .034 & & .046 & .003 & .000 \\
\hline & $\mathrm{N}$ & 48 & 48 & 48 & 48 & 48 & 48 \\
\hline \multirow{3}{*}{$\begin{array}{l}\text { Supplier } \\
\text { partnering }\end{array}$} & $\begin{array}{l}\text { Pearson } \\
\text { Correlat } \\
\text { ion }\end{array}$ & $.510^{* *}$ & .205 & $.289^{*}$ & 1 & $.391^{*}$ & $.337^{*}$ \\
\hline & $\begin{array}{l}\text { Sig. (2- } \\
\text { tailed) }\end{array}$ & .000 & .042 & .046 & & .006 & .019 \\
\hline & $\begin{array}{l}\mathrm{N} \\
\text { Pearson }\end{array}$ & 48 & 48 & 48 & 48 & 48 & 48 \\
\hline \multirow{3}{*}{ Six sigma } & $\begin{array}{l}\text { Correlat } \\
\text { ion }\end{array}$ & $.529^{* *}$ & $.551^{* *}$ & $.421^{* *}$ & $.391^{* *}$ & 1 & $.452^{* *}$ \\
\hline & $\begin{array}{l}\text { Sig. (2- } \\
\text { tailed) }\end{array}$ & .000 & .000 & .003 & .006 & & .001 \\
\hline & $\mathrm{N}$ & 48 & 48 & 48 & 48 & 48 & 48 \\
\hline \multirow{2}{*}{$\begin{array}{l}\text { Quality } \\
\text { management }\end{array}$} & $\begin{array}{l}\text { Pearson } \\
\text { Correlat } \\
\text { ion }\end{array}$ & $.642^{* *}$ & $.287^{*}$ & $.557^{* *}$ & $.337^{*}$ & $.452^{*}$ & 1 \\
\hline & $\begin{array}{l}\text { Sig. (2- } \\
\text { tailed) }\end{array}$ & .000 & .048 & .000 & .019 & .001 & \\
\hline
\end{tabular}


International Journal of Supply Chain and Logistics

ISSN 2520-3983 (online)

Vol.4, Issue No.1, pp 27 - 45, 2020

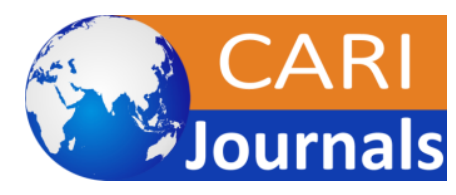

www.carijournals.org

$\mathrm{N} 48 \quad 48$
N*. Correlation is significant at the 0.01 level (2-tailed).
Source: Researcher (2017)

The results revealed that bench marking and competitiveness were positively and significantly related $(\mathrm{r}=0.578, \mathrm{p}=0.000)$. The results further indicated that continuous improvement and competitiveness were positively and significantly related $(r=0.620, p=0.000)$. It was further established that supplier partnering and competitiveness were positively and significantly related $(\mathrm{r}=0.510, \mathrm{p}=0.000)$. Similarly, the results showed that six sigma and competitiveness were positively and significantly related $(r=0.529, \mathrm{p}=0.000)$. Finally, the results revealed that quality management practices and competitiveness were positively and significantly related $(\mathrm{r}=0.642$, $\mathrm{p}=0.000$ ). This implies that an increase in any unit of the variables leads to an increase in competitiveness.

\subsection{Multiple Regression Analysis}

The results given in table 8 presents the fitness of the regression model used in explaining the study phenomena. Benchmarking, continuous improvement, supplier partnering, six sigma and quality management practices were found to be satisfactory variables in explaining competitiveness. This is supported by coefficient of determination also known as the R square of $72.2 \%$. This means that benchmarking, continuous improvement; supplier partnering, six sigma and quality management variables which represent SQM practices explain $72.2 \%$ of the variations in the dependent variable which is competitiveness. These results also imply that the model applied to link the relationship of the variables was satisfactory.

Table 8: Model Summary

\begin{tabular}{lrrrr}
\hline Model & R & R Square & Adjusted R Square & \multicolumn{2}{c}{$\begin{array}{c}\text { Std. Error of the } \\
\text { Estimate }\end{array}$} \\
\hline 1 & $.849^{\mathrm{a}}$ & .722 & .688 & .59842
\end{tabular}

a. Predictors: (Constant), quality management, benchmarking, supplier partnering, continuous improvement, six sigma

Source; Researcher 2017

Table 9 provides the results of ANOVA analysis. The results show that the overall model was statistically significant. Further, the results imply that the independent variables are good predictors of firm's competitiveness. This was supported by an F statistic of 21.769 and the reported $\mathrm{p}$ value (0.000) which was less than the conventional probability of 0.05 significance level.

Table 9: ANOVA

\begin{tabular}{llrrrrr}
\hline Model & & Sum of Squares & df & Mean Square & F & \multicolumn{1}{c}{ Sig. } \\
\hline \multirow{3}{*}{1} & Regression & 38.979 & 5 & 7.796 & 21.769 & $.000^{\mathrm{b}}$ \\
& Residual & 15.040 & 42 & .358 & & \\
& Total & 54.019 & 47 & & & \\
\hline
\end{tabular}


a. Dependent Variable: competitiveness

b. Predictors: (Constant), quality management, benchmarking, supplier partnering, continuous improvement, six sigma.

Source: Researcher (2017)

Regression of coefficients results in table 9 shows that benchmarking and competitiveness are positively and significantly related $(\mathrm{r}=0.825, \mathrm{p}=0.000)$. The table further indicates that continuous improvement and competitiveness of manufacturing firms in Nairobi are positively and significantly related $(\mathrm{r}=0.707, \mathrm{p}=0.002)$. It was further established that supplier partnering and competitiveness of manufacturing firms in Nairobi County were positively and significantly related $(\mathrm{r}=0.403, \mathrm{p}=0.006)$, six sigma and competitiveness of manufacturing firms in Nairobi County was also positively and significantly related $(\mathrm{r}=0.083, \mathrm{p}=0.049)$, quality management practices and competitiveness of manufacturing firms in Nairobi was also positively and significantly related $(\mathrm{r}=0.266, \mathrm{p}=0.009)$.

Table 10: Coefficients of variation.

\begin{tabular}{llrrrrr}
\hline Model & \multicolumn{2}{c}{$\begin{array}{c}\text { Unstandardized } \\
\text { Coefficients }\end{array}$} & $\begin{array}{c}\text { Standardized } \\
\text { Coefficients }\end{array}$ & t & Sig. \\
\cline { 2 - 4 } & \multicolumn{2}{c}{ B } & Std. Error & Beta & & \\
(Constant) & 1.126 & .346 & & 4.903 & .000 \\
benchmarking & .825 & .196 & .412 & 4.206 & .000 \\
& Continuous improvement & .707 & .217 & .329 & 3.257 & .002 \\
& Supplier partnering & .403 & .139 & .262 & 2.892 & .006 \\
& Six sigma & .083 & .138 & .067 & 0.604 & .049 \\
Quality management & .266 & .098 & .282 & 2.723 & .009 \\
\hline
\end{tabular}

a. Dependent Variable: competitiveness

Source: Researcher 2017

Thus, the optimal model for the study is;

Manufacturing firm's competitiveness $=1.126+0.825$ Benchmarking +0.707 Continuous improvement +0.403 Supplier partnering + 0.083 Six sigma +0.266 Quality management

\subsection{SUMMARY, CONCLUSION AND RECOMMENDATIONS}

\subsection{Summary of the Findings}

The results revealed that bench marking and competitiveness were positively and significantly related $(\mathrm{r}=0.578, \mathrm{p}=0.000)$. The results further indicated that continuous improvement and competitiveness were positively and significantly related $(r=0.620, p=0.000)$. It was further established that supplier partnering and competitiveness were positively and significantly related $(\mathrm{r}=0.510, \mathrm{p}=0.000)$. Similarly, the results showed that six sigma and competitiveness were positively and significantly related $(\mathrm{r}=0.529, \mathrm{p}=0.000)$. Finally, the results revealed that Quality management practices and competitiveness were positively and significantly related $(\mathrm{r}=0.642$, $\mathrm{p}=0.000)$. 
Benchmarking, continuous improvement, supplier partnering, six sigma and Quality management practices were found to be satisfactory variables in explaining competitiveness. This is supported by coefficient of determination also known as the $\mathrm{R}$ square of $72.2 \%$. This means that benchmarking, continuous improvement, supplier partnering, six sigma and quality management practices which represent SQM practices explain $72.2 \%$ of the variations in the dependent variable which is competitiveness.

\subsection{Conclusion}

Benchmarking, continuous improvement, supplier partnering, six sigma and quality management practices were positively and significantly related to competitiveness of manufacturing firms in Nairobi. Benchmarking, continuous improvement, supplier partnering, six sigma and quality management practices were found to be satisfactory variables in explaining competitiveness. This is supported by coefficient of determination also known as the $\mathrm{R}$ square of $72.2 \%$. The results indicate that the overall model was statistically significant. Further, the results imply that the independent variables are good predictors of firm competitiveness. This was supported by an $\mathrm{F}$ statistic of 21.769 and the reported $p$ value $(0.000)$ which was less than the conventional probability of 0.05 significance level.

\subsection{Recommendations}

The researcher recommended that firms should come up with as many benchmarking approaches and to also hold several of them so as to increase on adoption of effective mechanism that makes firms more competitive. The researcher having concluded that waste reduction in the company boosts on a manufacturing firm's competitiveness in the market. The recommendation given here is that firms should endeavor to maintain minimal wastes and defects in their places of operations as this is positively and significantly related to the competitiveness a firm will have in the market.

The study recommended that for enhanced quality management, manufacturing firms should institute and involve the support of strategic administration department to monitor their adoption and implementation. The study recommended that manufacturing firms should adopt various quality management practices for both internal operations and external activities so as to improve on the aspect of quality of these manufacturing firms.

\section{REFERENCES}

Adam, Jr, Corbett, M., Flores, E. and Harrison, J. (2007). An international study of quality improvement approach and firm performance, International Journal of Operations \& Production Management, 9:842-73.

Anderson, E.W., Fornell, C., Lehmann, D.R. (2004). Customer satisfaction, market share, and profitability: findings from Sweden, Journal of Marketing, 58 (3):53-66.

Anderson, J.C., Rugtusanatham, M., and Schroeder, R.G. (2004). A theory of quality management underlying the Deming management method, Academy of Management Review, 19(3): 472-509. 
International Journal of Supply Chain and Logistics

ISSN 2520-3983 (online)

Vol.4, Issue No.1, pp 27 - 45, 2020

$\underline{\text { www.carijournals.org }}$

Anderson, M., Sohal, A.S. (2009). A study of the relationship between quality management practices and performance in small businesses, International Journal of Quality \& Reliability Management, 16 (90): 859-877.

Backstrom, I. (2009). On the relationship between sustainable health and quality management", Mid Sweden University, Ostersund, doctoral dissertation

Beard, Thomas L. (2007). The Maturation of American Quality.Modern Machine Shop.April. Bricknell, G. (2006). Total quality revisited, Management Services, 60(1):18-20.

Brian L. (2007). The Future of Quality in the United States.National Underwriter Property \& Casualty-Risk \& Benefits Management.December 16, 1997.

Broetzmann, S.M., Kemp, J., Rossano, M., Marwaha, J. (2005). Customer satisfaction-lip service or management tool?",Managing Service Quality, (5):13-18.

Buttle, F. (2007).ISO 9000: Marketing Motivations and Benefits." International Journal of Quality \& Reliability Management.July 1997. 36

Capon, N., Farley, J.U., Hoeing, S. (2000). Determinants of financial performance: a metaanalysis, Management Science, 36 No.10, pp.1143-1159.

Choi, T.Y., Eboch, K. (2008). The TQM paradox: relations among TQM practices, plant performance, and customer satisfaction, Journal of Operations Management, 17:59-75.

Conlin, M.(2008). Revealed at Last: The Secret of Jack Welch's Success.Forbes. January 26, 1998.

Cooper D.R. \& Schindler, (2006).Business Research Methods, (5thEdition), Boston Irwin, McGaw Hill, Inc.

Craig, C.S., Douglass, S.P. (1992). Strategic factors associated with market and financial performance, Quarterly Review of Economics and Business, 22(2):101-112.

Crane, A. B. (2007)., January Supplement). The wealth management debate: Is the latest planning Trend right for you. Journal of Financial Planning, 14-15.

Crosby, P.B. (1997), Quality is Free: The Art of Making Quality Certain, McGraw-Hill, New York, NY.

Dahlgaard, J., Kristensen, K., Kanji, G.K. (2002), Fundamentals of Total Quality Management: Process Analysis and Improvement, Taylor \& Francis Group, London,

Dale, B.G., Plunkett, J.J. (2005), Quality Costing, Chapman \& Hall, London, . 37

Davenport, Jerry, L., Jr., and Li-Ping Tang, L. (2006).Learning from Japanese Companies and Japanese Transplants in the United States.Employment Relations Today.Spring

Deming, W.E. (1996), Out of the Crisis, Massachusetts Institute of Technology Center for Advanced Engineering Study, Cambridge, MA.

Deming, W.E. (2004). The New Economics for Industry, Government, Education, 2nd ed., Massachusetts Institute of Technology Center for Advanced Engineering Study, Cambridge, MA. 
International Journal of Supply Chain and Logistics

ISSN 2520-3983 (online)

Vol.4, Issue No.1, pp 27 - 45, 2020

$\underline{\text { www.carijournals.org }}$

Edwards, R., Sohal, A.S. (2003).The human side of introducing total quality management: two case studies from Australia, International Journal of Manpower, 24(5), 551-567.

Eldridge, S., Balubaid, M., Barber, K.D. (2006). Using a knowledge management approach to support quality costing, International Journal of Quality \& Reliability Management, 23 (1): 81-101.

Eriksson, H., Hansson, J. (2002). The impact of TQM on financial performance, Measuring Business Excellence, 6 (4):44-54.

Eriksson, H., Johansson, F., Wiklund, H. (2003). Effects of in-company quality awards on organizational performance, Total Quality Management \& Business Excellence, 14(2):235242.

Garvin, D.A. (1997). Competing on the eight dimensions of quality, Harvard Business Review, 101-109

Gaspersz, V. (2005). Total Quality Management, Jakarta:GramediaPustakanUtama Press

Harrington, H.J. (2001), Business Process Improvement: The Breakthrough Strategy for Total Quality, Productivity, and Competitiveness, McGraw-Hill, New York, NY,

Heller, Robert. (2004). Fourteen Points that the West Ignore at Its Peril. Management Today.

Hendricks, B., Singhal, R. (1996). Quality awards and the market value of the firm: an empirical investigation, Management Science, 42(3):415-36.

Hendricks, K.B., Singhal, V.R. (2006). Quality awards and the market value of the firm: an empirical investigation, Management Science, 42(3):415-436.

Hendricks, K.B., Singhal, V.R. (2007). Does implementing an effective TQM program actually improve operating performance, Management Science, Vol. 43 No.9, pp.1258-1274.

Henricks, M. (2006). Make No Mistake. Entrepreneur.

Jung, J. and Wang, Y. (2006). Relationship between total quality management (TQM) and continuous improvement of international project management (CIIPM), Tec novation, 26 (5), 716-722

KAM (2017). Association of Kenya Manufacturers, Retrieved on 17 July, 2017

Kamau, N. (2013). Quality management in manufacturing organizations-employees' perception: a case study of Bamburi cement ltd, published MBA Project, University of Nairobi

Kelly, K. and Maxwell, E. (2003). Sample Size for Multiple Regression: Obtaining Regression Coefficients that are Accurate, Journal of Psychological Association, 8(3):305-Joiner. 